\title{
Diagnostic aspects in surgical treatment of Fallot-type DORV (Differential diagnosis)
}

\author{
Karimov O. Kh. ${ }^{1}$, Siromaha S. O. ${ }^{2}$, Dziuriy I.V. ${ }^{2}$, Abralov Kh. K. ${ }^{1}$, Lazorishinetz V. V. ${ }^{2}$ \\ ${ }^{1}$ Republic Specialized Center of Surgery named after academician V. Vakhidov (Tashkent, Uzbekistan) \\ ${ }^{2}$ National M. M. Amosov Institute of Cardiovascular Surgery National Academy of Medical Sciences \\ of Ukraine (Kiyv, Ukraine)
}

\begin{abstract}
In the article, in respect of the comparative aspect, there are considered data of non-invasive general clinical diagnostic methods, as well as angiography in patients with adjacent heart defects as tetralogy of Fallot and double outlet right ventricle (Fallot-type). 196 patients with Fallot-type DORV were included in the first group and 124 patients with tetralogy of Fallot - in the second comparative group. The results of general clinical diagnostic methods had descriptive form. The gold standard for differential diagnosis is the echocardiographic study, which, when using the original method, showed the high reliability of differential diagnosis of Fallot-type DORV.
\end{abstract}

Key words: congenital heart disease, double-outlet right ventricle, echocardiography, diagnosis, pediatric surgery.

Since 1939, when Farber and Harris excluded double outlet right ventricle from the TGA classification [1], but this defect became an individual nosological entity. Considering DORV in this aspect, it should be pointed to the diversity of clinical picture in patients with different variants of this defect. Due to this "marginality" of the defect [2], clinical picture can be the same as for large VSD or tetralogy of Fallot, or transposition of the great arteries. Regarding Fallot-type DORV, according to all anatomical signs, except transposition of the great arteries, it is similar to its "adjacent" defect - tetralogy of Fallot [3]. Thus, the criterion of determination of this defect is unclear and "rule $50 \%$ " remains the non-objective basis for establishing the diagnosis, especially when it concerns tetralogy abnormality variant $[2,4,5]$. In this study, we want to assess our experience in diagnostics of this variant of double outlet right ventricle.

Study objective. To define the most indicative differential signs of Fallot-type DORV.

Material and methods. Since 1991 to 2016, in a retrospective way, we studied data of 196 patients with Fallot-type DORV, who were allocated to the first group and 124 patients with tetralogy of Fallot, who were allocated to the second comparative group. Therefore, the main study group included 196 patients with Fallot-type DORV, among whom, male patients were 123 (62.7\%), and female patients - 73 (37.3\%). Determination of Fallot-type DORV was based on "rule $50 \%$ ". Clinical examination of patients consisted of studying the subjective and objective data. Subjective part of the examination included history taking and complaints of the patients at first hand from their words and their close relatives (more often from parents).

The objective part of the examination included such general clinical methods as ECG registration, X-ray chest examination, and echocardiography (ECG). From 2000 to 2016, we used our own method of echocardiographic diagnosis of the concerned defect. This method was patented by us (patent No. 20021210762).

Catheterization of the cardiac cavities and angiocardiography were conducted using the standard method with the rate of 50-80 frames per minute. This method of examination, being interventional and complicated, was not used in all cases. It was performed in $70(35.7 \%)$ cases only.

Results and discussion. Determination of double outlet right ventricle is still unclear. Specifically, morphological diversity did not allow highlighting this defect as an individual nosological entity for a long time. The question that has to be answered is - how should we differentiate this defect from its "adjacent" tetralogy of Fallot in the most accurate way? Term "adjacent", according to our reckoning, is justifiably used in this case, as according to data received from literature $[2,4,5]$ and as seen from our observation, overriding of aorta over interventricular septum in $40 \%$ or in $60 \%$ is presented by similar symptoms and data of the examination. In general, in the determination of this pathology as an individual nosological entity, many authors understand term "DORV" as an abnormality of ventricular-arterial connection, in which both great vessels originate wholly or in large part from the right ventricle [6]. Revolution in terminological understanding was made by Dr. J. W. Kirklin when he proposed a famous " $50 \%$ rule". It says that if one great artery arises wholly or nearly so from the right ventricle(RV) and other more than $50 \%$ from it, the condition us termed DORV [2]. The main anatomical factor of double outlet right ventricle, in these cases, is the relationship of the great vessels with structures of the right 
Table 1

Subjective and objective signs in patients with DORV (Fallot-type) and TF

\begin{tabular}{lcc} 
Signs & DORV (n=196) & $\begin{array}{c}\text { Tetralogy of Fallot } \\
(\mathbf{n = 1 2 4 )}\end{array}$ \\
\hline \multicolumn{3}{c}{ Subjective signs } \\
\hline Dyspnea & $178 / 36^{* *}(90.8 \%)$ & $115 / 24^{* *}(92.7 \%)$ \\
\hline $\begin{array}{l}\text { Rapid } \\
\text { fatigability }\end{array}$ & $196(100 \%)$ & $124(100 \%)$ \\
\hline Tachycardia & $105(53.5 \%)$ & $56(45.2 \%)$ \\
\hline Squatting & $36(18.4 \%)$ & $9(7.2 \%)$ \\
\hline Syncope & $28(14.3 \%)$ & $22(17.7 \%)$ \\
\hline \multicolumn{3}{c}{ Objective signs } \\
\hline Cyanosis & $189 / 57^{*}(96.4 \%)$ & $116 / 21^{*}(93.5 \%)$ \\
\hline Nail clubbing & $104(53.1 \%)$ & $57(45.9 \%)$ \\
\hline Functional state & & \\
of patients & $12(6.1 \%)$ & - \\
NYHA I & $81(41.3 \%)$ & $35(28.2 \%)$ \\
NYHA II & $98(50 \%)$ & $67(54 \%)$ \\
NYHA III & $5(2.6 \%)$ & $22(17.7 \%)$ \\
NYHA IV &
\end{tabular}

Notice: ${ }^{* *}-$ dyspnea at rest, ${ }^{*}$ - acute cyanosis

ventricle and ventricular septal defect, which is the only outflow from the left ventricle [5]. We obtained data during the examination and the use of such general diagnostic methods, such as the ECG study or X-ray examination, which did not satisfy our question. They showed that patients with Fallot-type DORV have a more severe clinical course. So, they serve especially for a description of the state of patients.

To define the most optimal differential criteria for Fallot-type DORV, there was conducted the evaluation of examination data Data presented in Table 1 highlight the similarity of the clinical picture in both heart diseases.

However, even according to these data, it can be specified that the state of patients with Fallot-type DORV at admission was more severe.

In accordance with the data obtained with the help of laboratory examination methods, expression of hypoxemia, which we considered according to hemoglobin content and arterial oxygen percent saturation $\left(\mathrm{SaO}_{2}\right)$ revealed to be reliably higher in the second group. Thus, blood saturation in Fallot-type DORV, in average, was $82.3 \pm 8.7 \%$ and revealed itself as reliably lower than in tetralogy of Fallot $(88 \pm 7.02 ; \mathrm{p}<0,001)$, while hemoglobin content was higher $(161 \pm 28.6 \mathrm{~g} / \mathrm{L}$ versus $139.6 \pm 23.3 \mathrm{~g} / \mathrm{L} ; \mathrm{p}<0.001)$. These data can show only impliedly that due to Fallot-type DORV at the level of ventricles, there is larger mixing of arterial and venous blood, associated with the acute drift of cone septum to the right [2].

$\mathrm{X}$-ray examination of heart in the spectrum of instrumental and diagnostic measures was also ineffective.
Table 2

Values of the cardiothoracic index in both groups

\begin{tabular}{lcc}
$\begin{array}{l}\text { Degrees of heart } \\
\text { enlargement }\end{array}$ & $\begin{array}{c}\text { Tetralogy of } \\
\text { Fallot } \\
(\mathbf{n}=124)\end{array}$ & $\begin{array}{c}\text { Fallot-type } \\
\text { DORV } \\
(\mathbf{n}=196)\end{array}$ \\
\hline Norm & $87(70.1 \%)$ & $72(54.9 \%)$ \\
\hline Cardiomegaly & $37(29.9 \%)$ & $44(33.6 \%)$ \\
\hline Significant cardiomegaly & - & $15(11.5 \%)$
\end{tabular}

According to cardiothoracic index, values of which are presented in Table 2 demonstrated the degree of heart enlargement and myocardial decompensation.

Results of electrocardiography in these groups were insignificantly different (Table 3 ). However, in patients with Fallot-type DORV, in the first group, there were observed cases of arrhythmia with a lower incidence or even absence.

To determine the anatomy of the defect and its differential diagnosis, the most reasonable is the use of such instrumental diagnostic methods as echocardiography and angiography.

Thus, the characteristics of VSD play a huge role in the adequate correction of the defect in both groups $[2,7]$. Its anatomy in both groups of patients, in most cases, was similar. Data characterizing ventricular septal defect (VSD), one of the components of the defects, are presented in Table 4.

As Tables 4 demonstrated in both groups, ventricular septal defect had subaortic localization. In 23 (11.7\%) cases, among patients with Fallot-type DORV, its localization was doubly committed, that correspond to data received by Griffin M. L. et al. and Hara Y. et al. [8, 9]. However, we do not deny that this localization of the defect can be present in tetralogy of Fallot, which was observed in a series of patients examined by Vargas F. J. et al. [10]. Size of VSD, which in

\section{Table 3}

Results of ECG in Fallot-type DORV and tetralogy of Fallot

\begin{tabular}{lcc} 
Variants & $\begin{array}{c}\text { Tetralogy of Fallot } \\
(\mathbf{n = 1 2 4 )}\end{array}$ & $\begin{array}{c}\text { Fallot-type } \\
\text { DORV (n=196) }\end{array}$ \\
\hline No hypertrophy & 10 & 3 \\
\hline RV hypertrophy & 114 & 187 \\
\hline LV hypertrophy & - & 13 \\
\hline \multicolumn{1}{c}{ Rentricular hypertrophy } & - & 13 \\
\hline \multicolumn{1}{c}{ and conductivity disturbance } \\
\hline Lower-atrial & - & 9 \\
\hline Supraventricular & - & 6 \\
tachycardia & - & 3 \\
\hline Wandering pacemaker & - & 24 \\
\hline Extrasystole & - & 1 \\
\hline Ciliary arrhythmia & 7 & 36 \\
\hline Incomplete RBBB & - & 12 \\
\hline AV block & &
\end{tabular}


Table 4

Characteristics of VSD

\begin{tabular}{lccc}
$\begin{array}{l}\text { Characteristics of } \\
\text { VSD }\end{array}$ & $\begin{array}{c}\text { Tetralogy of } \\
\text { Fallot } \\
(\mathbf{n}=124)\end{array}$ & $\begin{array}{c}\text { Fallot-type } \\
\text { DORV } \\
(\mathbf{n}=196)\end{array}$ & $\mathbf{p}$ \\
\hline \multicolumn{4}{c}{ Localization of VSD } \\
\hline Subaortic & $124(100 \%)$ & $173(88.3 \%)$ & $<0.005$ \\
\hline Doubly committed & \multicolumn{4}{c}{$23(11.7 \%)$} \\
\hline \multicolumn{4}{c}{ Size of defect } \\
\hline$\emptyset V S D \geqslant \emptyset$ aorta & $124(100 \%)$ & $168(85.7 \%)$ & $<0.0001$ \\
\hline$\emptyset V S D<\emptyset$ aaorta & & $28(14.3 \%)$
\end{tabular}

the case with DORV, is the only lead from the left ventricle, has a large importance in performing the intraventricular tunneling. Thus, restrictive VSD expresses itself as subaortic stenosis prior to operation, aggravating the state of patients. The need in its extension increases surgical risk in many times during operation [2]. Data from Table 4 demonstrates that in the presence of tetralogy of Fallot, the diameter of the defect had an optimal length in all cases, whereas in the presence of Fallot-type DORV, it was smaller than diameter of the aorta in 28 (14.3\%) cases. Such incidence of a restrictive ventricular septal defect in the pathology studied by us coincides with data obtained by Mauran P. et al., although they notice rareness of combination of such anatomy of the ventricular septal defect and right ventricular outflow tract obstruction [11].

The last one is the further anatomical component of the defects in both groups. Pulmonary artery stenosis is divided into three types. Characteristics of RVOT stenosis are presented in Table 5.

As Table 5 showed, in both study groups of patients, there were observed all three types of pulmonary artery stenosis. It should be noted that, although such indicators, as pressure gradient between the right ventricle and pulmonary artery and Nakata index were "closer" to the norm in the second group, expression of hypoxemia was higher in the same category of patients. This fact talks of more pronounced mixing of arterial and venous blood at the level of ventricles in patients with Fallot-type DORV. From the point of view of a surgeon, the high frequency of the infundibular and mixed type of obstruction of RVOT obstruction in these groups, is of interest to the anatomy of the coronary arteries in this area [12]. Wilcox B. R. et al. subdivided abnormalities of the CA observed in these patients into 3 variants [13]. Table 6 presents variants of abnormalities of the coronary arteries, which were found in our study.

Data of the table show that abnormalities of the coronary arteries are observed in both groups. Group of the patients with Fallot-type DORV is distinguished by a higher incidence of this abnormality $(\mathrm{p}<0.01)$ and its diversity. These data consist with data obtained by Gordillo L. et al. [14], which the author explains as the embryological devel-
Table 5

Types of pulmonary artery stenosis in tetralogy of Fallot and Fallot-type of DORV

\begin{tabular}{lccl} 
& $\begin{array}{c}\text { Tetralogy of } \\
\text { Fallot }(\mathbf{n = 1 2 4 )}\end{array}$ & $\begin{array}{c}\text { Fallot-type of } \\
\text { DORV }(\mathbf{n}=196)\end{array}$ & $\mathbf{p}$ \\
\hline Ventricular SP & $9(7.2 \%)$ & $7(3.5 \%)$ & \\
\hline Infundibular SP & $37(29.8 \%)$ & $35(17.8 \%)$ & \\
\hline Mixed SP & $78(62.9 \%)$ & $154(78.5 \%)$ & \\
\hline PA gradient & $85 \pm 7.1$ & $77.1 \pm 20.7$ & $<0.0001$ \\
\hline PA index (Nakata) & $164 \pm 80.4$ & $225 \pm 119.03$ & $<0.0001$
\end{tabular}

Table 6

Variants of abnormalities of the CA according to the groups of patients

\begin{tabular}{lccc} 
& $\begin{array}{c}\text { Tetralogy of Fallot } \\
(\mathbf{n}=124)\end{array}$ & $\begin{array}{c}\text { Fallot-type DORV } \\
(\mathbf{n = 1 9 6 )}\end{array}$ & $\mathbf{p}$ \\
\hline Conus artery & $2(1.6 \%)$ & $12(6.1 \%)$ & $<0.01$ \\
\hline ADA from RCA & $4(3.2 \%)$ & $17(8.4 \%)$ & $<0.01$ \\
\hline $\begin{array}{l}\text { ADA from } \\
\text { the right aortic } \\
\text { sinus }\end{array}$ & - & $3(1.5 \%)$ & - \\
\hline Total & $6(4.8 \%)$ & $32(16.03 \%)$ & $<0.01$
\end{tabular}

opment of heart with this pathology. This is also connected with the high incidence of concomitant defects in DORV [2] (Table 7).

Table 7

Concomitant defects in DORV (Fallot-type) and tetralogy of Fallot

\begin{tabular}{lcc} 
Concomitant defects & $\begin{array}{c}\text { Tetralogy of } \\
\text { Fallot } \\
(\mathbf{n = 1 2 4 )}\end{array}$ & $\begin{array}{c}\text { Fallot-type } \\
\text { DORV } \\
(\mathbf{n = 1 9 6 )}\end{array}$ \\
\hline Multiple VSD & 3 & 6 \\
\hline PDA & 2 & 14 \\
\hline PA atresia & - & 3 \\
\hline LV hypoplasia & - & 6 \\
\hline Dextrocardia & - & 7 \\
\hline Left SVC & - & 6 \\
\hline TV stradling & - & 1 \\
\hline RV or LV hypoplasia & - & 2 \\
\hline ASD & 6 & 40 \\
\hline Mitral insufficiency & - & 3 \\
\hline Tricuspid insufficiency & - & 8 \\
\hline Subaortic stenosis & - & 9 \\
\hline Hypoplastic aortic arch & - & 1 \\
\hline Partial anomalous pulmonary & - & 4 \\
venous connection & - & 4 \\
\hline Aortic insufficiency & $11(8.9 \%)$ & $114(58.1 \%)$
\end{tabular}




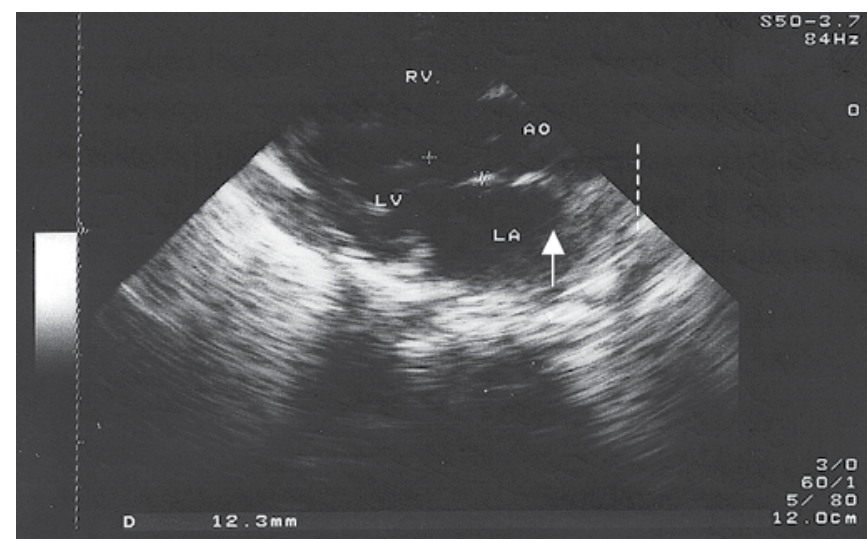

Figure 1. Echocardiogram of patient H. with DORV (Fallot-type). The VSD margin is indicated by an arrow

It should be mentioned that since the first description of this abnormality, it was proposed that a few variants of its differential diagnosis from tetralogy of Fallot, with the use of such anatomical "markers", as the absence of mitroaortal contact or ventricular cone [15]. However, results of examination of patients showed that the absence of mitral aortal fibrous contact and ventricular cone occurred in the group of patients with DORV (Fallot-type) and, correspondingly, in $83(42.1 \%)$ and $67(34.2 \%)$ cases. Perhaps their use for distinguishing these defects would be appropriate with the greater frequency of their occurrence in our patients. Our data are approved by the results of the examination and other scientists [16].

At present, a well-recognized criterion of DORV remains "50\% rule" [2]. However, as it was indicated by Y. Lecompte, it preserves a large share of relativity [16]. Thus, a cardiologistsurgeon can simulate DORV in the outlet of cardiac structures in the incorrect project. Since 2002, we used a new method of ECG diagnostics, which allowed objectifying this rule by mathematical computation of the degree of drift of aortic ring to the right-ventricular side over the VSD (Figure 1).

Results of this method are presented in Table 8.

Table 8 showed that drift index in tetralogy of Fallot was less than 1 and reliably differed from OI in Fallot-type DORV, which was more than 1 . The degree of drift of aortal valve over VS in all cases with tetralogy of Fallot was less than or equal to $50 \%$, whereas in all cases with Fallot-type DORV, it was more than $50 \%$. Results of this examination were approved by

\section{Table 8}

Overriding index in DORV (Fallot-type) and TF

Overriding index Degree of overriding

\begin{tabular}{lcc}
\hline Tetralogy of Fallot & $0.92 \pm 0.15$ & $47.4 \pm 4.8$ \\
\hline DORV (Fallot-type) & $2 \pm 0.59$ & $65.6 \pm 6.05$ \\
\hline$p$ & $<0.0001$ & $<0.0001$
\end{tabular}

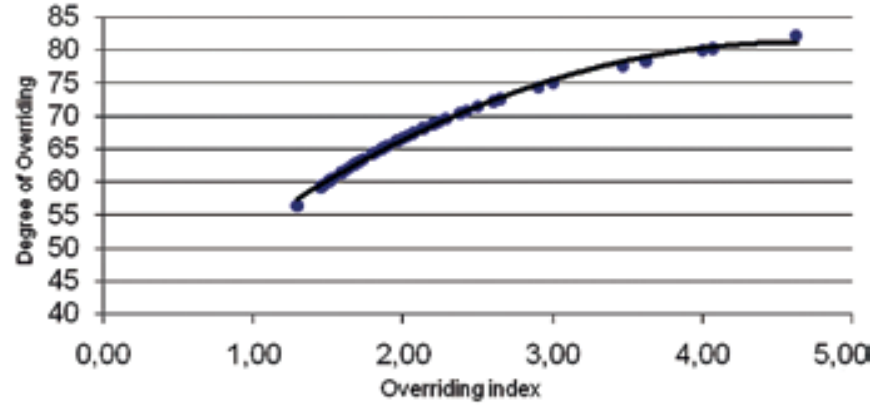

Figure 2. Regression equation obtained by least square method appeared as:

Degree of overriding $=-5.0711^{*} \mathrm{DI} 2+33.076 \mathrm{DI}+21.443$

The correlation coefficient of model values with original values is equal to $R=0.9993(p<0.0001)$

intraoperative data. Dependence between these two indicators appears in the form of the approximating curve (Figure 2).

Figure 2 demonstrated differences in ranges, in which OI is observed in the presence of tetralogy of Fallot and Fallot-type DORV. It follows that the use of this diagnostic method allows us to distinguish reliably double outlet right ventricle and tetralogy of Fallot, whereupon it was impossible to do on the basis of other anatomical peculiarities of the defect studied by us. Establishing accurate diagnosis and acknowledgment of anatomical peculiarities give a surgeon an opportunity to choose the most optimal tactics of surgical treatment, which immediately reflects even on its results.

Conclusion. This study was based on retrospective analysis of data of a large cohort of patients with Fallottype DORV and patients with tetralogy of Fallot. Comparative analysis showed the clinical picture in both cardiac defects are similar. However, the functional state of patients with DORV when admission is the most severe. Similarly, in these patients, there was reliably detected a larger number of concomitant cardiac defects. Noninvasive methods of examination, except ECG, revealed as non-informative. ECG and angiocardiography allow us to define reliably anatomical peculiarities in DORV. Therewith, anatomical markers of this defect, in particular, the absence of mitral aortal fibrous contact and ventricular cone, were detected, correspondingly, in 83 (42.1\%) and 67 (34.2\%) cases. Our original method of diagnostic ECG demonstrated the high reliability of differential diagnostics of Fallot-type DORV.

\section{References}

1. Manner J, Seidl W, Steding G. Embryological observations on the morphogenesis of double-outlet right ventricle with subaortic ventricular septal defect and normal arrangement of the great arteries. Thorac Cardiovasc Surg. 1995 Dec;43(6):307-12.

2. Kirklin JW, Barratt- Boyes BG . Double -Outlet Right ventricle In: Kirklin JW, Barratt-Boyes BG, eds Cardiac Surgery 3nd edition New York: Churchill Livingstone, 2013. 
3. Henry L. Walters III, MD, Constantine Mavroudis, MD, Christo I. Tchervenkov, MD, Jeffrey P. Jacobs, MD, Franëcois Lacour-Gayet, MD, and Marshall L. Jacobs, MD Congenital Heart Surgery Nomenclature and Database Project: Double Outlet Right Ventricle. Ann Thorac Surg 2000;69: S249-63.

4. Henry L. Walters III. Conuses and discontinuities: To be or not to be in double-outlet right ventricle The Journal of Thoracic and Cardiovascular Surgery, Vol. 154, Issue 2, p605-606, April 13, 2017.

5. Ameneh Ebadi, Ameneh Ebadi, Diane E. Spicer, Carl L. Backer, MD, F. Jay Fricker, MD, Robert H. Anderson, MD Double-outlet right ventricle revisited. The Journal of thoracic and cardiovascular surgery. August 2017. Volume 154, Issue 2, Pages 598-604.

6. Veronica Spadotto, Carla Frescura, Siew Yen Ho, Gaetano Thiene. The concept of double inlet-double outlet right ventricle: a distinct congenital heart disease. Cardiovascular pathology.January-February, 2017 Volume 26, Pages 39-44.

7. Olivier Villemain, MD, Emre Belli, MD, Magalie Ladouceur, MD, Lucile Houyel, MD, Zakaria Jalal, MD, Virginie Lambert, MD, PhD, Mohamed Ly, MD, Pascal Vouhŭ, MD, PhD, Damien Bonnet, MD, PhD Impact of anatomic characteristics and initial biventricular surgical strategy on outcomes in various forms of double-outlet right ventricle. The Journal of Thoracic and Cardiovascular Surgery. September 2016Volume 152, Issue 3, Pages 698-706.e3.

8. Griffin ML, Sullivan ID, Anderson RH, Macartney FJ. Doubly committed subarterial ventricular septal defect: new morphological criteria with echocardiographic and angiocardiographic correlation. Br Heart J 1988 Apr;59(4):474-9.

9. Hara Y, Ashida Y, Okada M, Kuroda H, Araki T, Mori T. Successful repair of double-outlet right ventricle (SDL) with doubly committed ventricular septal defect and pulmonary stenosis using Rastelli's procedure. Nippon Kyobu Geka Gakkai Zasshi 1988 Apr;36(4):569-73.

10. Vargas FJ, Kreutzer GO, Pedrini M, Capelli H, Rodriguez Coronel A. Tetralogy of Fallot with subarterial ventricular septal defect. Diagnostic and surgical considerations. J Thorac Cardiovasc Surg 1986 Nov;92(5):908-12.

11. Mauran P, Breviere GM, Rey C, Friedli B, Dupuis C. Obstructions to pulmonary ejection and restrictive interventricular septal defects. Arch Mal Coeur Vaiss 1988 May;81(5):649-53.

12. Shoujun Li, MD, Kai Ma, MD, PhD, Shengshou $\mathrm{Hu}$, MD, Zhongdong Hua, MD, Keming Yang, MD, Jun Yan, MD, Qiuming Chen, MD, PhD Surgical outcomes of 380 patients with double outlet right ventricle who underwent biventricular repair The Journal of Thoracic and Cardiovascular Surgery. September 2014Volume 148, Issue 3, Pages 817-824.

13. Anderson RH, Ho SY, Wilcox BR. The surgical anatomy of ventricular septal defect part IV: double outlet ventricle. J Card Surg 1996 Jan-Feb;11(1):2-11.

14. Gordillo, L, Faye-Petersen, O, de la Cruz, MV et al, Coronary arterial patterns in double-outlet right ventricle. Am J Cardiol. 1993;71:1108-1110.

15. Lecompte Y,Batisse A, DiCarlo D, Double-outlet right ventricle: a surgical synthesis. Adv Card Surg 1993;4:109-36.

16. Meriem Mostefa-Kara MD, DamienBonnet MD, PhD, Emre Belli MD, Elie Fadel MD, Ph, Lucile Houyel MD. Anatomy of the ventricular septal defect in outflow tract defects: Similarities and differences The Journal of Thoracic and Cardiovascular Surgery Volume 149, Issue 3, March 2015, Pages 682-688.e1.

\title{
Діагностичні аспекти в хірургічному лікуванні подвійного відходження магістральних судин від правого шлуночка тетрадного типу (диференціальна діагностика)
}

\author{
Карімов О. Х. ${ }^{1}$, Сіромаха С. О. ${ }^{2}$, Дзюрій І. В. ${ }^{2}$, Абралов Х. К. ${ }^{1}$, Лазоришинець В. В. ${ }^{2}$ \\ ${ }^{1}$ Республіканський спеціалізований центр хірургії імені академіка В. Вахідова (Ташкент, Узбекистан) \\ ${ }^{2}$ ДУ «Національний інститут серцево-судинної хірургії імені М. М. Амосова НАМН України» (Київ)
}

Подвійне відходження магістральних судин від правого шлуночка (ПВМС від ПШ) - це складна вроджена вада серця, яка є однією з вад із порушеннями розвитку вентрикулоартеріального зв'язку серця. Необхідно відзначити різноманітність клінічної картини у пацієнтів із різними варіантами цієї вади. Внаслідок «граничності» цієї вади клінічна картина може бути такою самою, як при великому ДМШП, тетраді Фалло або транспозиції магістральних судин. Розглядуваний нами тетрадний варіант ПВМС від ПШ за всіма анатомічними ознаками (за винятком відходження магістральних судин) подібний до «суміжної» 3 ним вади - тетради Фалло. Так, досі неясним є критерій визначення цієї вади, і «правило 50\%» залишається необ’єктивною підставою для постановки діагнозу, особливо якщо це стосується тетрадного варіанту аномалії.

У цьому дослідженні був проаналізований наш досвід у діагностиці даного варіанту подвійного відходження магістральних судин від правого шлуночка. Метою дослідження було визначити найбільш показові диференціальні ознаки подвійного відходження магістральних судин від правого шлуночка тетрадного типу. Ретроспективно були проаналізовані дані 320 пацієнтів. 3 них 196 пацієнтів із ПВМС від ПШ тетрадного типу ввійшли до першої групи, а 124 пацієнтів із тетрадою Фалло склали другу порівняльну групу. У порівняльному аспекті представлено дані неінвазивних загальноклінічних методів дослідження, ехокардіографії та ангіокардіографії. Як показало дослідження, результати загальноклінічних методів дослідження мали описовий характер. Золотим стандартом для диференціальної діагностики слугує ехокардіографічне дослідження, яке при застосуванні оригінальної методики показало високу вірогідність диференціальної діагностики ПВМС від ПШ тетрадного типу.

Ключові слова: вроджена вада серия, подвійне відходження магістральних судин від правого шлуночка, ехокардіографія, діагностика, педіатрична хірургія. 